Sādhanā Vol. 40, Part 6, September 2015, pp. 1989-1999. (C) Indian Academy of Sciences

\title{
Influence of palm oil fuel ash on fresh and mechanical properties of self-compacting concrete
}

\author{
HOSSEIN MOHAMMADHOSSEINI, A S M ABDUL AWAL* and \\ ABDUL HAQ EHSAN
}

Faculty of Civil Engineering, Universiti Teknologi Malaysia, 81310 UTM Skudai, Johor, Malaysia

e-mail: hofa2018@yahoo.com; asmawal@yahoo.com; abdulhaqehsan@gmail.com

MS received 18 February 2015; revised 3 April 2015; accepted 17 April 2015

\begin{abstract}
This paper presents experimental results of some fresh and hardened state properties of self-compacting concrete (SCC) incorporating palm oil fuel ash (POFA). Three concrete mixes namely ordinary Portland cement (OPC) concrete i.e. concrete with $100 \%$ OPC as control, and concrete with $30 \%$ and $60 \%$ POFA having different water/binder (w/b) ratios of $0.4,0.45$ and 0.5 were prepared. Filling ability, passing ability and segregation resistance of SCC along with strength properties were determined and compared with those of the OPC based SCC. Test results revealed that replacement of POFA in general decreased the workability of concrete with acceptable range. The compressive strength, however, increased with lower w/b ratio and lower replacement of ash. The splitting tensile and flexural strength values have also followed the same trend. The results obtained and the observation made in this study suggest that POFA can suitably be used as supplementary cementing material in SCC.
\end{abstract}

Keywords. Self-compacting concrete; palm oil fuel ash; filling ability; passing ability; segregation resistance; strength.

\section{Introduction}

Self-compacting concrete (SCC) is considered as a concrete which can be placed and compacted under its self-weight with little or no vibration, and at the same time, it is cohesive enough to be handled without segregation or bleeding (Ozawa et al 1989). SCC is used to facilitate and ensure proper filling and good structural performance of restricted areas and heavily reinforced structural members. These characteristics translate into substantial reduction in labor cost and construction time and better working environment by eliminating the impact of vibration. The SCC technology can permit the construction industries to optimize material use, generate economic benefits, and build structures that are sound economically and environmentally by reducing the noise pollution, improving the filling capacity of highly congested structural members,

${ }^{*}$ For correspondence 
facilitating constructability and ensuring good structural performance. The first production of SCC was developed in Japan in the late 1980s, needs excessive cement content and the usage of expensive chemical admixtures in spite of its high cost to be mainly used for highly congested reinforced structures in seismic regions (Ozawa et al 1989; Yurugi 1998; Domone 2006, 2007). Recently, SCC concrete has gained wide use in many countries for different applications and structural configurations.

With the advances in cement and concrete technology the application of various pozzolanic materials has also been increased. Perhaps the latest addition to the ash family is palm oil fuel ash (POFA), a waste material obtained on burning of palm oil husk and palm kernel shell as fuel in palm oil mill boilers that has been identified as a good pozzolanic material. In view of the utilization of pozzolanic material as a supplementary cementing material, extensive research works have been carried out in examining various aspects of fresh and hardened state properties of SCC. Recent researcher endeavor lead to the improvement of new type of SCC by substituting a high percentage of cement, with several supplementary cementitious materials (SCM) such as silica fume, ground granulated blast-furnace slag, fly ash and rice husk ash (Safiuddin et al 2011a, b; Lachemi et al 2003; Dinakar et al 2013; Siddique 2011; Liu 2010). The use of such waste products not only imparts high fluidity and better cohesiveness of the concrete mix, but also improves mechanical and durability properties of concrete (Abdul Awal \& Shehu 2013; Abdul Awal \& Hussin 1999; Uysal \& Yilmaz 2011; Safiuddin et al 2011a, b; Hossain \& Lachemi 2010).

Research works on the use of POFA in SCC, however, are not many. Study on the utilization of POFA by Alsubari et al (2014) and Safiuddin et al (2011a, b) has been limited to the use of $20 \%$ POFA in concrete. Although, the possibility of SCC with up $80 \%$ cement replaced by fly ash has been studied (Liu 2010; Siddique 2011; Bouzoubaa \& Lachemi 2011; Uysal \& Sumer 2011). They also found that fly ash has negative effects on passing ability, consistence retention and hardened concrete properties such as strength. Considering the availability and pozzolanic behavior of POFA, extensive research works are being conducted at the Universiti Teknologi Malaysia evaluating the potential benefit of high volume POFA in concrete. As a part of this program investigation was also carried out to study the effect of higher volume of up to $60 \%$ POFA by weight of cement on the performance of SCC in terms of fresh and hardened state properties.

\section{Materials and test method}

\subsection{Collection and preparation of palm oil fuel ash}

POFA, as above-mentioned earlier, is a waste product received in the form of ash on burning palm oil husk and palm kernel shell as fuel in palm oil mill boiler. In this study, POFA was obtained from a factory in Johor, southern state of Malaysia. The collection of ash was done at the foot of the flue tower where all the fine ashes are trapped while escaping from the burning chamber of the boiler. After collection the raw POFA was dried in an oven at a temperature of $110{ }^{\circ} \mathrm{C}$ for $24 \mathrm{~h}$. Later, it was sieved through $300-\mu \mathrm{m}$ sieve in order to remove large particles and other impurities and reduce the carbon content to prevent glassy phase of crystallization. To increase fineness, the ashes were then ground in a modified Los Angeles abrasion test machine having 10 stainless steel bars of $12 \mathrm{~mm}$ diameter and $800 \mathrm{~mm}$ long.

\subsection{Concrete materials and mixes}

Ordinary Portland cement (ASTM Type I) was used in the study. A saturated surface dry mining sand with fineness modulus of 2.3 , passing through $4.75 \mathrm{~mm}$ sieve having specific gravity and 
water absorption of 2.6 and of $0.70 \%$ respectively was used as fine aggregate. The coarse aggregate was $10 \mathrm{~mm}$ crushed granite with specific gravity of 2.7 , having water absorption of $0.5 \%$. RHEOBUILD 1100 (HG), a polymer based superplasticizer was used in order to improve workability of concrete at a percentage ranging from $2 \%$ to $4 \%$. In this study, the mixture proportions of the SCC were determined according to the guidelines given in EFNARC (2002). Nine concrete mixes were made: three with OPC alone and the others with OPC replaced by weights of $30 \%$ and $60 \%$ POFA, having water/binder ratios of $0.4,0.45$ and 0.50 . The relative mix proportions of concrete mixes are given in table 1.

\subsection{Test methods}

The fresh state properties of concrete were conducted through filling ability, passing ability and segregation resistance tests in the laboratory. The filling ability of SCC was evaluated by slump flow and Orimet flow time tests. The slump flow was determined by the mean diameter of the mass of concrete after release from a standard Abrams cone. The J-Ring test was conducted to measure the passing ability, Abrams cone and steel J-ring with round steel bars of $10 \mathrm{~mm}$ diameter was used. The L-box test was also conducted to detect the blocking ratio. For segregation resistance, $\mathrm{V}$-funnel at $\mathrm{T}_{5 \mathrm{~min}}$ was performed. All tests (shown in figure 1) were conducted in accordance with EFNARC specifications and guidelines for SCC (EFNARC 2002), and ASTM standards (ASTMC 16112009; ASTMC 16212009). Compressive strength test was conducted with $100 \mathrm{~mm}$ cube specimens according to BS 1881-116:1983. Cylinders measuring $100 \mathrm{~mm} \times 200 \mathrm{~mm}$ were prepared for splitting tensile strength test as specified by ASTM C496 (2011) and $100 \mathrm{~mm} \times$ $100 \mathrm{~mm} \times 500 \mathrm{~mm}$ prism specimens were made for testing the flexural strength with reference to ASTM C293 (2010). A non-destructive test using ultrasonic pulse velocity (UPV) was conducted with the aid of Proceed apparatus and associated transducer as shown in figure 2. The test was conducted before the compressive strength test on cube samples. All the laboratory tests were performed at an average room temperature of $27^{\circ} \mathrm{C}$ with the relative humidity, $\mathrm{RH}$ of $80 \pm 5 \%$.

\section{Experimental results and discussion}

\subsection{Properties of palm oil fuel ash}

POFA is gray in color that becomes darker with increasing amounts of unburned carbon content. The particles have an extensive range of sizes but they are relatively spherical; a typical electron

Table 1. Details of the mix proportions of SCC.

\begin{tabular}{|c|c|c|c|c|c|c|c|c|}
\hline \multirow{2}{*}{$\begin{array}{l}\text { Mix } \\
\text { code }\end{array}$} & \multirow[b]{2}{*}{ W/B } & \multirow{2}{*}{$\begin{array}{l}\text { Cement } \\
\left(\mathrm{kg} / \mathrm{m}^{3}\right)\end{array}$} & \multicolumn{2}{|c|}{ POFA } & \multirow{2}{*}{$\begin{array}{l}\text { Water } \\
\left(\mathrm{kg} / \mathrm{m}^{3}\right)\end{array}$} & \multirow{2}{*}{$\begin{array}{c}F A \\
\left(\mathrm{~kg} / \mathrm{m}^{3}\right)\end{array}$} & \multirow{2}{*}{$\begin{array}{c}\mathrm{CA} \\
\left(\mathrm{kg} / \mathrm{m}^{3}\right)\end{array}$} & \multirow{2}{*}{$\begin{array}{c}\mathrm{SP} \\
\left(\mathrm{kg} / \mathrm{m}^{3}\right)\end{array}$} \\
\hline & & & $(\%)$ & $\left(\mathrm{kg} / \mathrm{m}^{3}\right)$ & & & & \\
\hline S0-1 & 0.50 & 512 & 0 & - & 256.0 & 790 & 790 & 10.20 \\
\hline S0-2 & 0.45 & 512 & & - & 230.4 & 790 & 790 & 10.20 \\
\hline S0-3 & 0.40 & 512 & & - & 204.8 & 790 & 790 & 10.20 \\
\hline S3-1 & 0.50 & 359 & 30 & 153 & 263.0 & 775 & 775 & 15.30 \\
\hline S3-2 & 0.45 & 359 & & 153 & 236.7 & 775 & 775 & 15.30 \\
\hline S3-3 & 0.40 & 359 & & 153 & 210.4 & 775 & 775 & 15.30 \\
\hline S6-1 & 0.50 & 206 & 60 & 306 & 270.0 & 760 & 760 & 21.50 \\
\hline S6-2 & 0.45 & 206 & & 306 & 243.0 & 760 & 760 & 21.50 \\
\hline S6-3 & 0.40 & 206 & & 306 & 216.0 & 760 & 760 & 21.50 \\
\hline
\end{tabular}



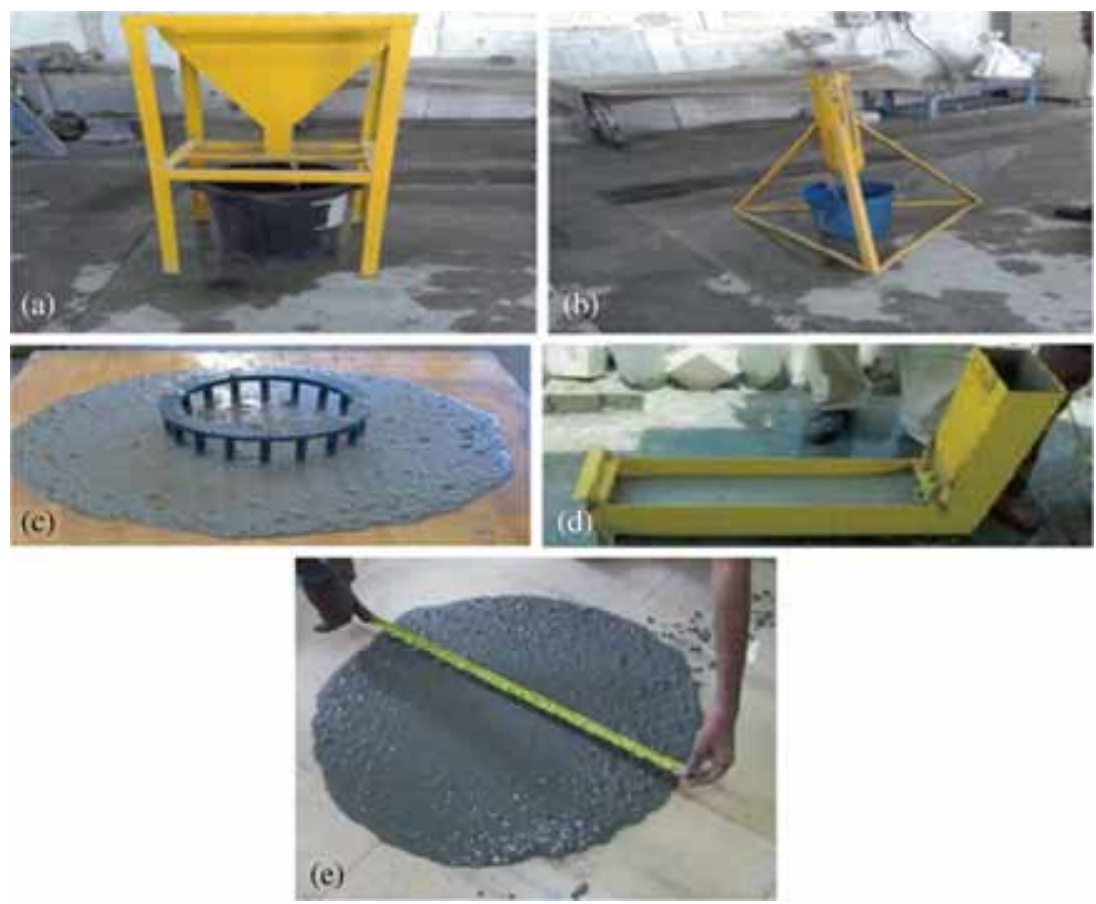

Figure 1. Fresh concrete testing devices: (a) V-Funnel apparatus, (b) Orimet flow time apparatus, (c) J-Ring in-conjunction with slump-flow, (d) L-Box test apparatus, (e) Slump flow.

micrograph of POFA is shown in figure 3. The physical properties and chemical composition of OPC and POFA are presented in table 2. It can be observed that POFA has higher Blaine fineness and lower specific gravity as compared to OPC. The chemical composition suggests that POFA contains low calcium oxide; with $\mathrm{SiO}_{2}+\mathrm{Al}_{2} \mathrm{O}_{3}+\mathrm{Fe}_{2} \mathrm{O}_{3}$ content greater than $70 \%$ which satisfies the requirement to be pozzolanic, and may be classified between class $\mathrm{F}$ and class $\mathrm{C}$ according to the ASTM C618 (2012). It is interesting to note that the present-day classification

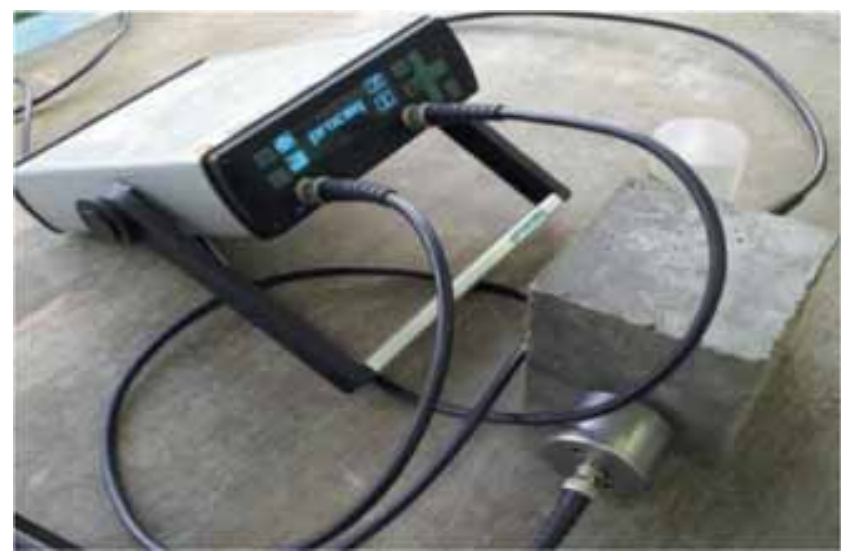

Figure 2. Ultrasonic pulse velocity testing device. 


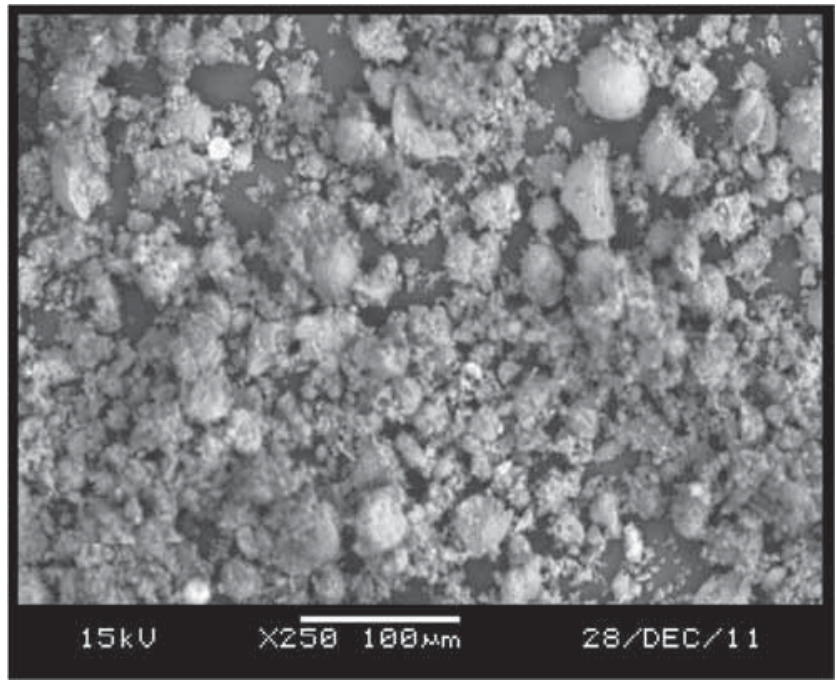

Figure 3. Scanning electron micrograph of POFA.

system for grouping of ashes into class $\mathrm{N}$, class $\mathrm{F}$ and class $\mathrm{C}$ is not adequate to appraise their total usefulness, particularly for agricultural ashes. Considering the origin and type this ash is, however, neither of class $\mathrm{C}$ nor of class $\mathrm{F}$.

\subsection{Properties of fresh concrete}

Figure 4 reveals flow characteristics obtained under various tests. It can be observed that the replacement of POFA by Portland cement has a significant effect on the flow properties of SCC. It can be seen that as the POFA content increases the demand for superplasticizer also increases, as illustrated in table 1 . The reason could be that at higher replacement there was an increase in the paste volume of the SCC, due to the low specific gravity of POFA.

It is to note that as the POFA content increases, the slump flow decreases. The nine mixtures showed slump flow values between 600 and $690 \mathrm{~mm}$ displaying the capability of concrete to flow under its own weight. The $30 \%$ replacement at w/b ratio of 0.4 presented a slump flow value of $635 \mathrm{~mm}$, whereas the $60 \%$ replacements exhibited a value of $600 \mathrm{~mm}$ for the same w/b ratio.

Table 2. Physical properties and chemical composition of OPC and POFA.

\begin{tabular}{lccccc}
\hline Physical properties & OPC & POFA & Chemical composition $(\%)$ & OPC & POFA \\
\hline Specific gravity & 3.15 & 2.42 & $\mathrm{SiO}_{2}$ & 20.4 & 62.60 \\
Blaine fineness $\left(\mathrm{cm}^{3} / \mathrm{g}\right)$ & 3,990 & 4,930 & $\mathrm{Al}_{2} \mathrm{O}_{3}$ & 5.20 & 4.65 \\
Passing sieve $10 \mu \mathrm{m}(\%)$ & 19 & 33 & $\mathrm{Fe}_{2} \mathrm{O}_{3}$ & 4.19 & 8.12 \\
Soundness $(\mathrm{mm})$ & 1.0 & 2.0 & $\mathrm{CaO}$ & 62.39 & 5.70 \\
& & $\mathrm{MgO}$ & 1.55 & 3.52 \\
& & $\mathrm{~K}_{2} \mathrm{O}$ & 0.005 & 9.05 \\
& & $\mathrm{SO}_{3}$ & 2.11 & 1.16 \\
& & $\mathrm{LOI}_{2}$ & 2.36 & 6.25 \\
& & $\mathrm{SiO}_{2}+\mathrm{Al}_{2} \mathrm{O}_{3}+\mathrm{Fe}_{2} \mathrm{O}_{3}$ & - & 75.37 \\
\hline
\end{tabular}



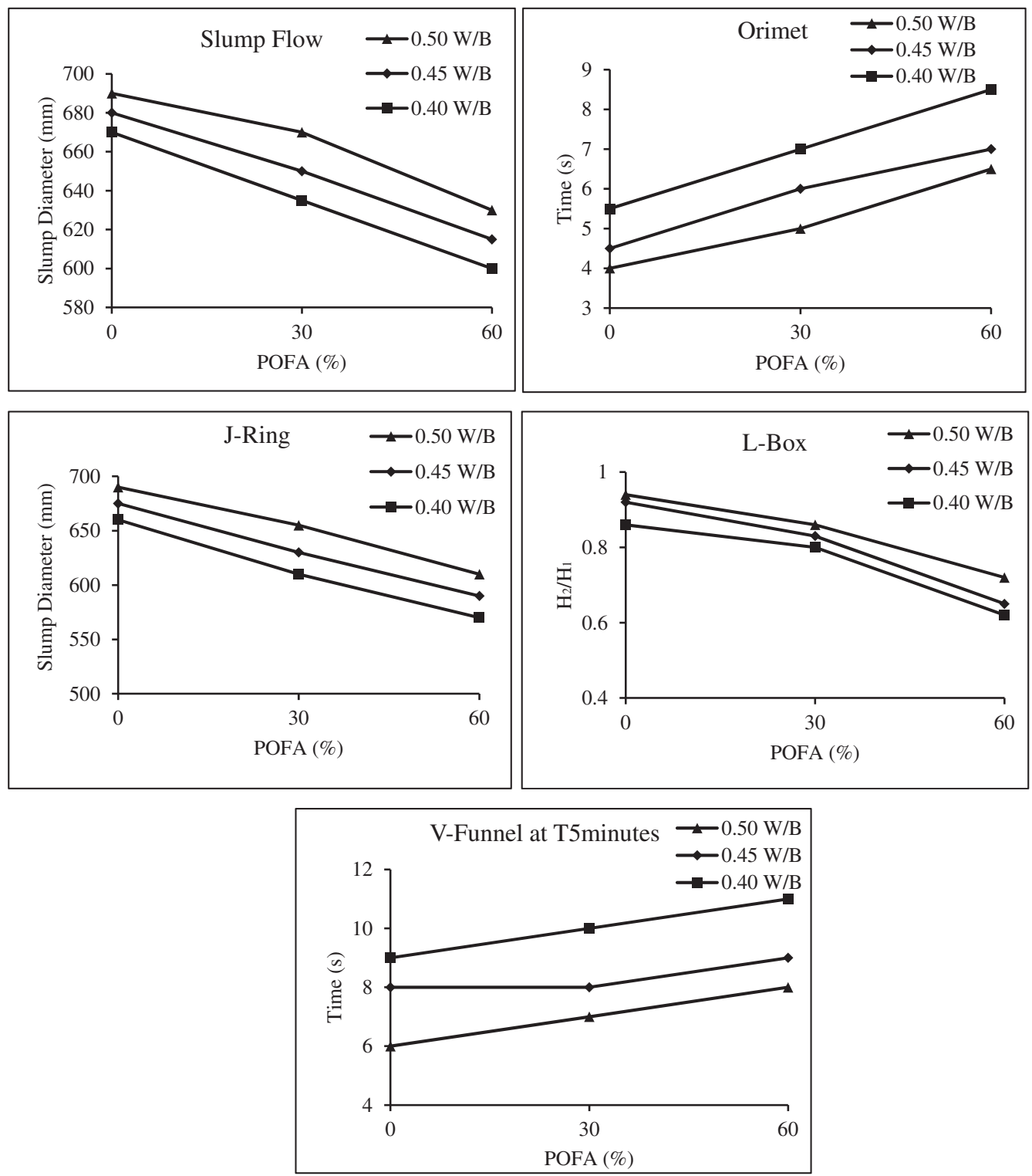

Figure 4. Fresh properties of SCC with respect to POFA replacement at different w/b ratios.

According to the European guidelines for self-compacting concrete (EFNARC 2002) slump flow of $650 \pm 50 \mathrm{~mm}$ is needed for SCC, and all the concrete mixes developed here have fulfilled the requirements. The J-ring values were also obtained in the range of 570 and $690 \mathrm{~mm}$ where all the concrete mixes developed satisfactory performance.

In all mixes $\mathrm{V}$-funnel at $\mathrm{T}_{5 \mathrm{~min}}$ test, however, showed significant variations. For example, $\mathrm{SCC}$ mixtures containing POFA content of $30 \%$ and $60 \%$ presented values of 10 and $11 \mathrm{~s}$ for w/b of 0.4 , whereas the OPC concrete showed a value of $9 \mathrm{~s}$. Due to higher w/b ratio the mobility of concrete obviously was higher that consequently lowered time. It is to note that the Orimet flow 
time for all concrete mixes ranged between 4 and $8.5 \mathrm{~s}$ showing the trend of higher time requirement with the increase in the ash volume. In case of L-box, the $\mathrm{H}_{2} / \mathrm{H}_{1}$ value decreased with the increasing amount of POFA, the results being varied from 0.92 to 0.94 . The results obtained on fresh properties of SCC, in general, are quite satisfactory and corroborate the research finding by other researchers (Dinakar et al 2013; Safiuddin et al 2011a, b).

\subsection{Mechanical properties}

3.3a Compressive strength: Compressive strength of SCC mixes was determined at 7, 28 and 90 days of curing. The test results, illustrated in figure 5 reveal the variation of compressive strength values with the variation in POFA content and water/binder ratios for a different curing period. Obviously, higher compressive strength development is attributed to lower water content in the concrete mix at all ages. Because of the vary pozzolanic nature, all POFA concrete mixes at early ages were found to have lower strengths than the control mix; at later ages however, significant improvements are shown to occur in POFA concrete for all water/binder ratios. For example, the compressive strength development at 28-day reached to $33.5,37.0$ and $42.5 \mathrm{MPa}$ for $30 \%$ and also $29.5,30.5$ and $33.0 \mathrm{MPa}$ for $60 \%$ of POFA content for w/b ratios of $0.5,0.45$ and 0.4 respectively as compared to $37.5,40.5$ and $45.0 \mathrm{MPa}$ of OPC based SCC for the same $\mathrm{w} / \mathrm{b}$ ratios. It is interesting to note that effect of $\mathrm{w} / \mathrm{b}$ ratio in the development of strength of concrete containing high volume POFA was more significant than that of plain concrete. This phenomenon can be due to the higher demand of water for pozzolanic materials like POFA to complete the hydration process. Similar observations have been made by Alsubari et al (2014),
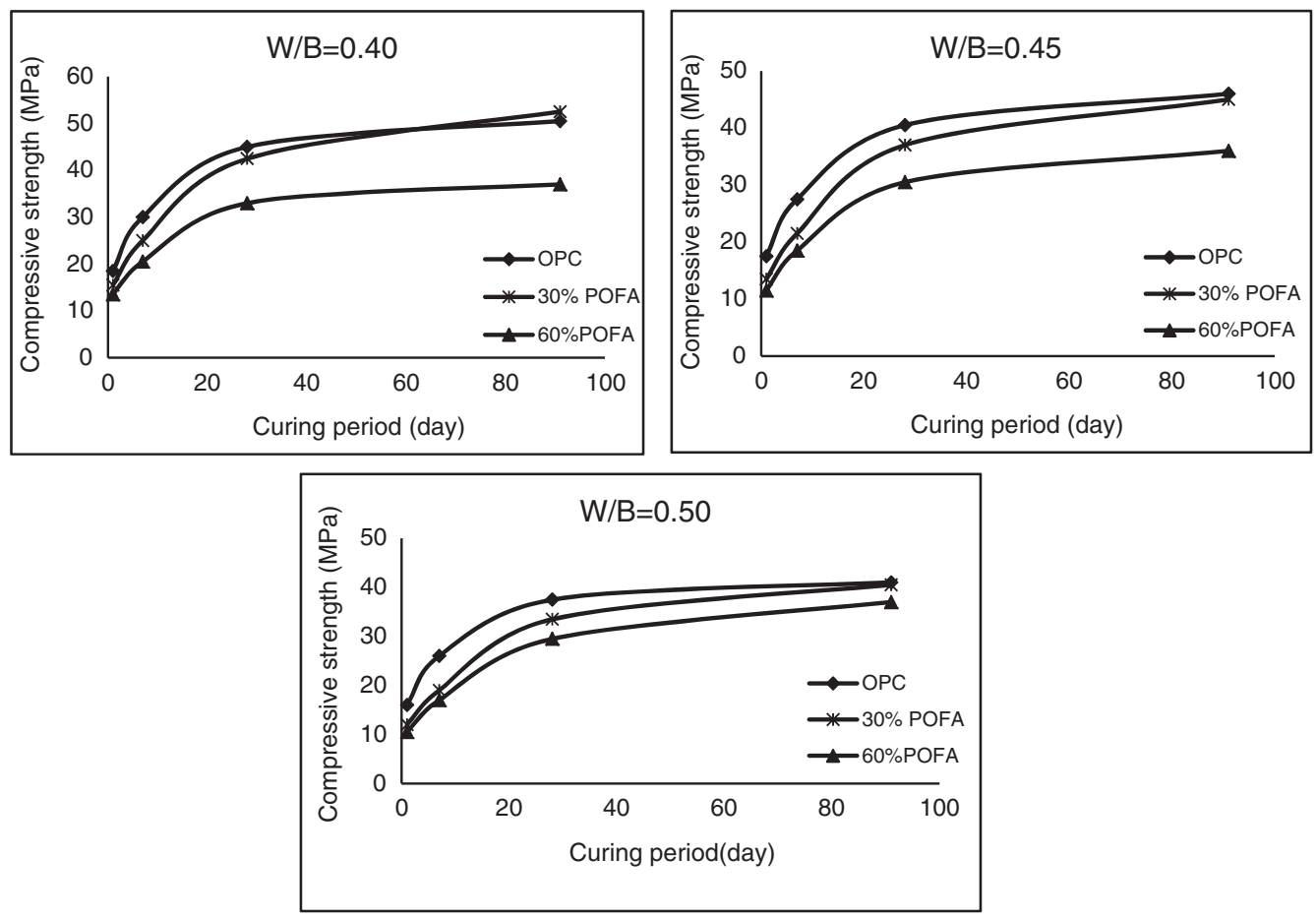

Figure 5. Compressive strength development of various concrete mixtures. 


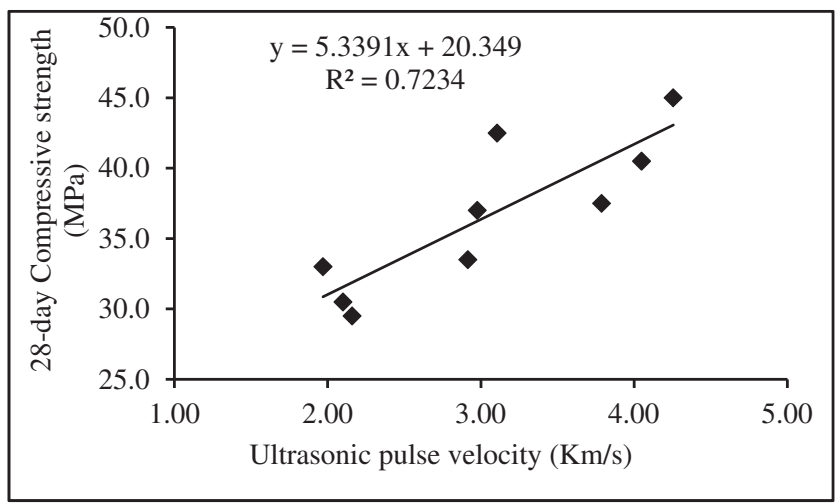

Figure 6. Relationship between the compressive strength and ultrasonic pulse velocity.

Hossain \& Lachemi (2010), and Safiuddin et al (2011a, b). This result is in aggrement with results reported by Liu (2010), Bouzoubaa \& Lachemi (2011) and Safiuddin et al (2011a, b) who investegated the effects of pozzolanic materials like fly ash and rice husk ash on the strength of the SCC.

Figure 6 reveals the relationship between compressive strength and UPV of OPC and POFA SCC at the age of 28 days. A direct relationship between the compressive strength and UPV can clearly be observed in these figures. The measured compressive strength values were used as response parameter with the UPV as their predicator parameter. A linear regression method was applied to correlate the experimental data resulting in Eq. (1), with a coefficient of determination $\mathrm{R}^{2}=0.72$ for all specimens.

$$
y=5.339 x+20.349
$$

3.3b Splitting tensile and flexural strength: The splitting tensile strength of both OPC and POFA based SCC for different w/b ratios measured at the curing period of 28 days are shown in figure 7. Data plotted in the figure clearly revealed that higher the ash content lower was the tensile strength. The tensile strength of concrete without any ash at w/b ratio of 0.45 was 4.28 MPa. A reduction in strength by $4.0 \%$ and $24.7 \%$ was recorded in concrete with $30 \%$ and

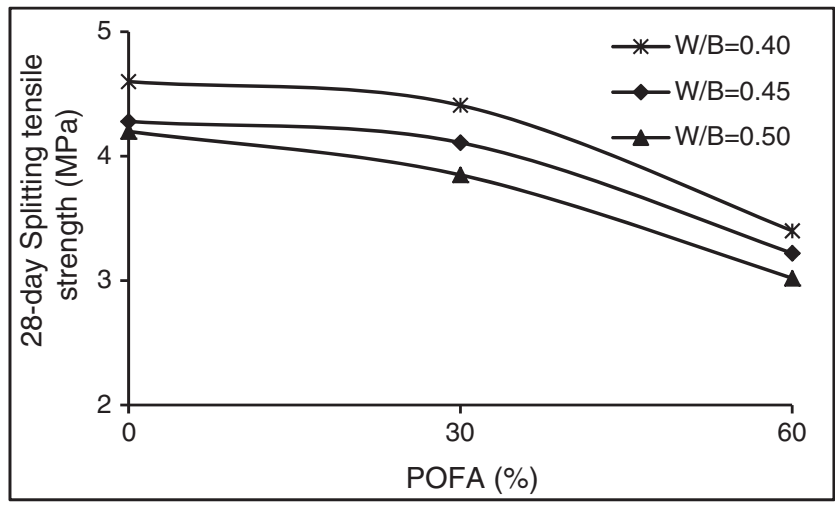

Figure 7. Splitting tensile strength of various concrete mixes. 
$60 \%$ POFA respectively for the same curing period of 28 days. Obviously, higher the w/b ratio lower was the tensile strength in all mixes. Similar observation has been made by Siddique et al (2012); they have studied the influence of water/powder ratio on strength properties of SCC containing coal fly ash and bottom ash and found that an increasing w/b ratio decreased the tensile strength of SCC.

The flexural strength of SCC mixtures at 28 days is presented in figure 8. A similar tendency like that of compressive and tensile strength has also been observed for the flexural strength of SCC specimens; higher the amount of POFA lower was the flexural strength value. Highest strength of 5.7 MPa was recorded for control mix with $0.4 \mathrm{w} / \mathrm{b}$ ratio, and for the same w/b ratio a value of 5.2 $\mathrm{MPa}$ was obtained for SCC containing 30\% POFA. Lowest flexural strength of 3.4 MPa was however, recorded for specimen containing $60 \%$ POFA having $0.50 \mathrm{w} / \mathrm{b}$ ratio, which is $32 \%$ lower than that of SCC with OPC alone. Such a trend has also been reported by Siddique (2011) and Nikbin et al (2014), who observed the effects of the different w/b ratios and pozzolanic materials content on the strength of the SCC.

\section{Relationship of compressive, splitting tensile and flexural strengths}

The results obtained from compression, splitting tensile and flexural tests and their relationships are displayed in figure 9. A linear regression method was used to correlate the experimental data resulting in the following Eqs. (2) and (3), and the coefficients of determination $\mathrm{R}^{2}$ were 0.91 and 0.92 respectively, which represent good confidence of relationship.

From the results, it has been shown that for the SCC incorporating POFA, the tensile and flexural strength values are closely related to compressive strength and the ratio of the strength development followed the pattern similar to that of the normal plain concrete. It can further be seen that, as the compressive strength increases, the splitting tensile strength also increases but at a lower rate following Eq. (2). The relationship between compressive and flexural strengths is also given in figure 9 having similar trend, expressed in Eq. (3). The observations made in this study suggest that all strength parameters for SCC containing POFA are within the typical values for normal plain concrete.

$$
y=9.1646 x+0.8236
$$

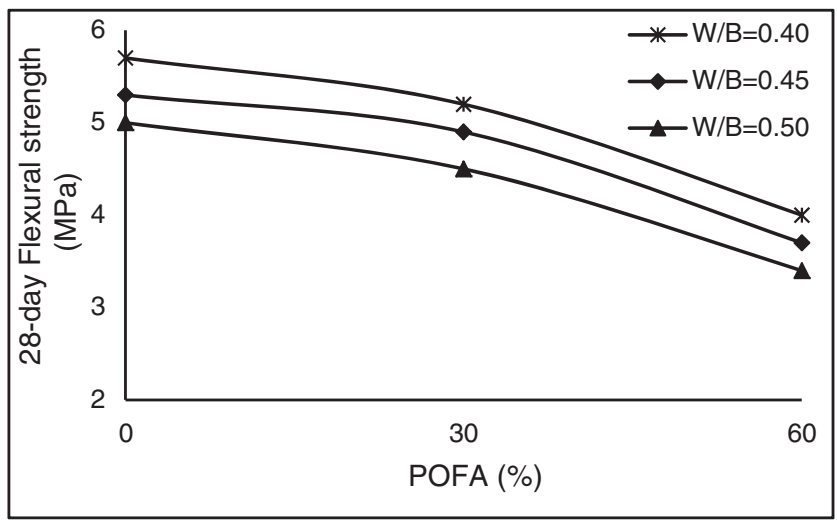

Figure 8. Flexural strength of various concrete mixes. 

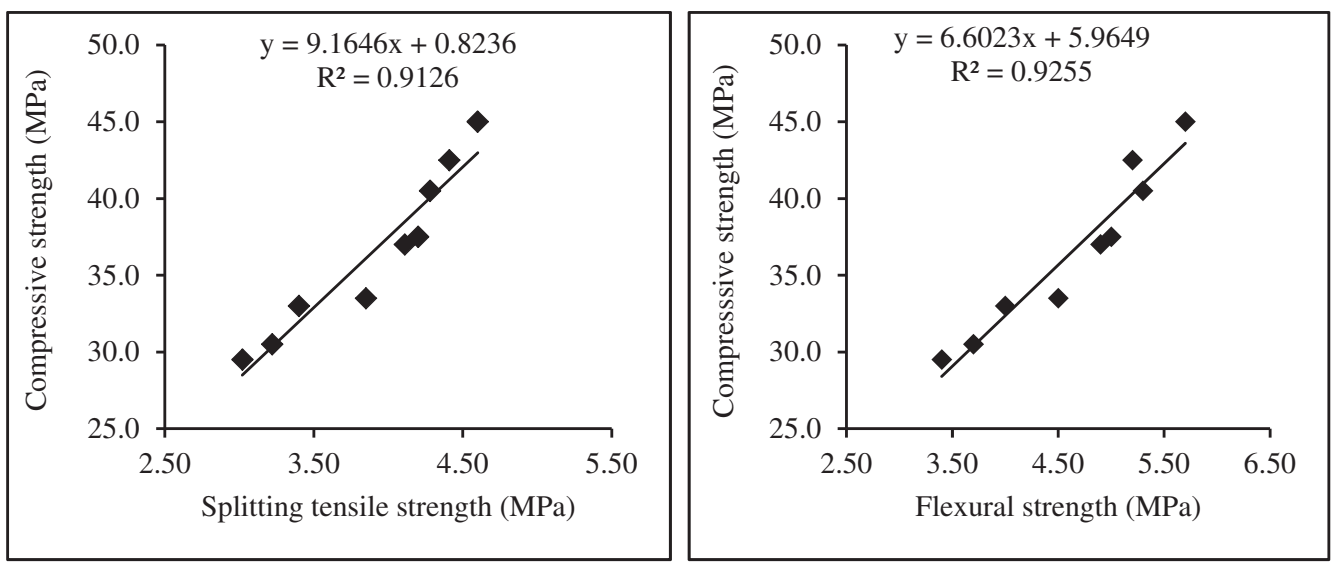

Figure 9. Relationship of the compressive, tensile and flexural strengths.

$$
y=6.6023 x+5.9649 .
$$

\section{Conclusions}

In this study the effects of the replacement levels $0,30 \%$ and $60 \%$ of POFA having variable w/b ratios on fresh and hardened state properties of SCC have been evaluated. It has been found that higher replacement of ordinary Portland cement by POFA resulted in lower workability of the SCC. However, the values obtained for all the workability tests are found to be satisfactory in terms of self-compaction. Although the application of POFA had a positive response in developing compressive strength, reduction in strength has been shown to occur in concrete with higher volume replacement of POFA; the values however, being within the suitable limits for structural applications. A similar trend like that of compressive strength has been observed for the tensile and flexural strengths of SCC specimens. A good relationship in strength values has been also found out in all mixes of SCC containing POFA. Time dependent behavior including durability aspects has been put forward as recommendation for future investigation as to explore the potential benefit of high volume POFA in SCC.

\section{Acknowledgements}

The authors are thankful to the technical support received from the staff of Structure and Materials laboratory of the Universiti Teknologi Malaysia (UTM) in conducting the experimental work.

\section{References}

Abdul Awal A and Hussin M 1999 Durability of high performance concrete containing palm oil fuel ash. In: Eighth International Conference on Durability of Building Materials and Components, 8 dbmc: 465-474

Abdul Awal A and Shehu I 2013 Evaluation of heat of hydration of concrete containing high volume palm oil fuel ash. Fuel 105: 728-731

Alsubari B, Shafigh P and Jumaat M Z 2014 The effect of palm oil fuel ash as a cement replacement material on selfcompacting concrete. Appl. Mech. Mater. 567: 529-534 
ASTM C618/C618M 2012 Standard specification for coal fly ash and raw or calcined natural pozzolan for use as a mineral admixture for concrete. American Society for Testing Materials

ASTM C1621/C1621M 2009 Standard test method for passing ability of self-consolidating concrete by J-ring. American Society for Testing Materials

ASTM C1611/C1611M 2009 Standard test method for slump flow of self-consolidating concrete. American Society for Testing and Materials

ASTM C293/C239M 2010 Standard test method for flexural strength of concrete (using simple beam with center-point loading). American Society for Testing Materials

ASTM C496/C496M 2011 Standard test method for splitting tensile strength of cylindrical concrete specimens. American Society for Testing Materials

Bouzoubaa N and Lachemi M 2011 Self-compacting concrete incorporating high volumes of class F fly ash preliminary results. Cement Concrete Res. 31: 413-420

BS 1881-116 1983 Testing concrete. Method for determination of compressive strength of concrete cubes. British Standard

Dinakar P, Kartik Reddy M and Sharma M 2013 Behaviour of self compacting concrete using Portland pozzolana cement with different levels of fly ash. Mater. Des. 46: 609-616

Domone P 2006 Self-compacting concrete: An analysis of 11 years of case studies. Cement Concrete Compos. 28: 197-208

Domone P 2007 A review of the hardened mechanical properties of self-compacting concrete. Cement Concrete Compos. 29: 1-12

EFNARC 2002 Specifications and guidelines for self-consolidating concrete. In: European Federation of Suppliers of Specialist Construction Chemicals (EFNARC)

Hossain K and Lachemi M 2010 Fresh, mechanical, and durability characteristics of self-consolidating concrete incorporating volcanic ash. J. Mater. Civil Eng. 22(7): 651-657

Lachemi M, Hossain K M, Lambros V and Bouzoub 2003 Development of cost-effective self-consolidating concrete incorporating fly ash, slag cement, or viscosity-modifying admixtures. ACI Mater. J. 100(5): 419-425

Liu M 2010 Self-compacting concrete with different levels of pulverized fuel ash. Constr. Build. Mater. 24: $1245-1252$

Nikbin I et al 2014 A comperhensive investegation into the effect of water to cement ratio and powder content on mechanical properties of self-compacting concrete. Constr. Build Mater. 57: 69-80

Ozawa K, Maekawa K, Kunishima H and Okamura H 1989 Performance of concrete based on the durability design of concrete structures. Chiang Mai, Thailand. 445-456

Safiuddin M, Abdus Salam M and Jumaat M Z 2011a Correlations between fresh properties of selfconsolidating concrete including palm oil fuel ash. Adv. Mater. Res. 250-253: 409-416

Safiuddin M, West J and Soudki K 2011b Flowing ability of the mortars formulated from self-compacting concretes incorporating rice husk ash. Constr. Build Mater. 25: 973-978

Siddique R 2011 Properties of self-compacting concrete containing class F fly ash. Mater. Des. 32: 15011507

Siddique R, Aggarwal P and Aggarwal Y 2012 Influence of water/powder ratio on strength properties of self-compacting concrete containing coal fly ash and bottom ash. Constr. Build Mater. 29: 73-81

Uysal M and Sumer M 2011 Performance of self-compacting concrete containing different mineral admixtures. Constr. Build Mater. 25: 4112-4120

Uysal M and Yilmaz K 2011 Effect of mineral admixtures on properties of self-compacting concrete. Cement Concrete Compos. 33: 771-776

Yurugi M 1998 Application of self-compacting concrete in Japan. In: Proceedings of 23rd OWICS conference, Singapore: CI-Premier Ptc. Ltd. 29-42 